\title{
The Impact of Intellectual Capital on Firm Performance of Manufacturing SMEs in Malaysia
}

\author{
Zainab M. Aljuboori ${ }^{1} \&$ Harcharanjit Singh ${ }^{2}$ \\ ${ }^{1,2}$ Azman Hashim International Business School, Universiti Teknologi Malaysia, Johor Bahru, Malaysia. \\ DOI: http://doi.org/10.38177/AJBSR.2021.3408
}

Copyright: $\odot 2021$ Zainab M. Aljuboori \& Harcharanjit Singh. This is an open access article distributed under the terms of the Creative Commons Attribution License, which permits unrestricted use, distribution, and reproduction in any medium, provided the original author and source are credited.

\section{ABSTRACT}

There are various factors from empirical studies that many factors influence firm performance. The purpose of this conceptual paper is to review the impact of intellectual capital as a unidimensional factor on the performance of manufacturing SMEs operating in Malaysia. The framework was developed after a systematic review of past literature. The present paper found the critical influence of the study's variables on firm performance. Furthermore, the study provided some understanding of how intellectual capital affects manufacturing SMEs' performance in Malaysia. Intellectual capital plays an important role in influencing a Manufacturing SMEs firm performance. The paper emphasizes the critical value of intellectual capital for SMEs owner/managers consideration when acting on behalf of their company, failing to experience poor performance. Resource-Based View $(R B V)$ theory underlies the conceptual framework and explains the relationship among variables. In addition, some implications of this conceptual model for theory and practice are discussed.

Keywords: Intellectual capital, Firm performance, Manufacturing SMEs, Malaysia, Resource-based view.

\section{Introduction}

A review of the existing literature stated that intellectual capital consists of multiple dimensions, where different authors have suggested different dimensions of intellectual capital. According to past study, scholars have a dispute about the definitions and dimensions of intellectual capital despite the consensus about the critical role of intellectual capital [1]. Another study argued that scholars until today could not agree on how many dimensions intellectual capital has and what the dimensions are [2].

While a long time ago, [3] has been narrowed the scope of many concepts into the conceptualization of intellectual capital, such as personal knowledge, incorporate organizational relationships, infrastructure, culture, routine, and intellectual property. However, the present conceptual paper studies intellectual capital as unidimensional, which combines all the factors mentioned. Intellectual capital contributes to organizations where intangible assets such as knowledge, professional skills, experience, customer relationships, information, database, and organizational structure are considered assets of a firm. These assets are efficiently employed to create value for the firm, improve the overall performance, and gain a competitive advantage [4,5].

Intellectual capital refers to the pursuit of effective use of knowledge that is embedded in human intellect, organizational workouts, and marketplace relationships [1]. It is posited that SMEs operate with many obstacles, including economic scarcity, skillful personnel, and in-residence formal structures and systems [6,7]. These issues would hinder SMEs from reaping the capacity of intellectual capital $[8,9]$.

Due to the overpowering acknowledgment of the positive role of intellectual capital, it plays a critical role in developing the countries, burgeoning track of research has started a deep exploration of intellectual capital in small and medium enterprises (SMEs). It works to grow countries' economies [10]. 


\section{Problem Statement}

SMEs' contributions toward the GDP are relatively low compared to developed countries [11]. In order to overcome these various challenges faced by Malaysian SMEs, productivity should be improved to remain competitive. Moreover, Malaysian SMEs must pay more attention and concern to the importance of enhancing the intellectual capital in SMEs to achieve overall competitiveness [10]. However, SMEs sectors in Malaysia had a steady GDP growth from 2014 to 2018, except for the manufacturing sectors. Compared with other SME sectors such as service or construction, manufacturing SMEs face a serious issue regarding GDP contribution, which declined from 21.7\% in 2014 to 20.0\% in 2018 (SME Corp, 2018), as shown in Figure 1. Manufacturing SMEs are recognized as a significant industry in its economy because they contribute as the second-largest share of GDP. The development of the issue has a substantial influence on the economy, as well as on Malaysia.

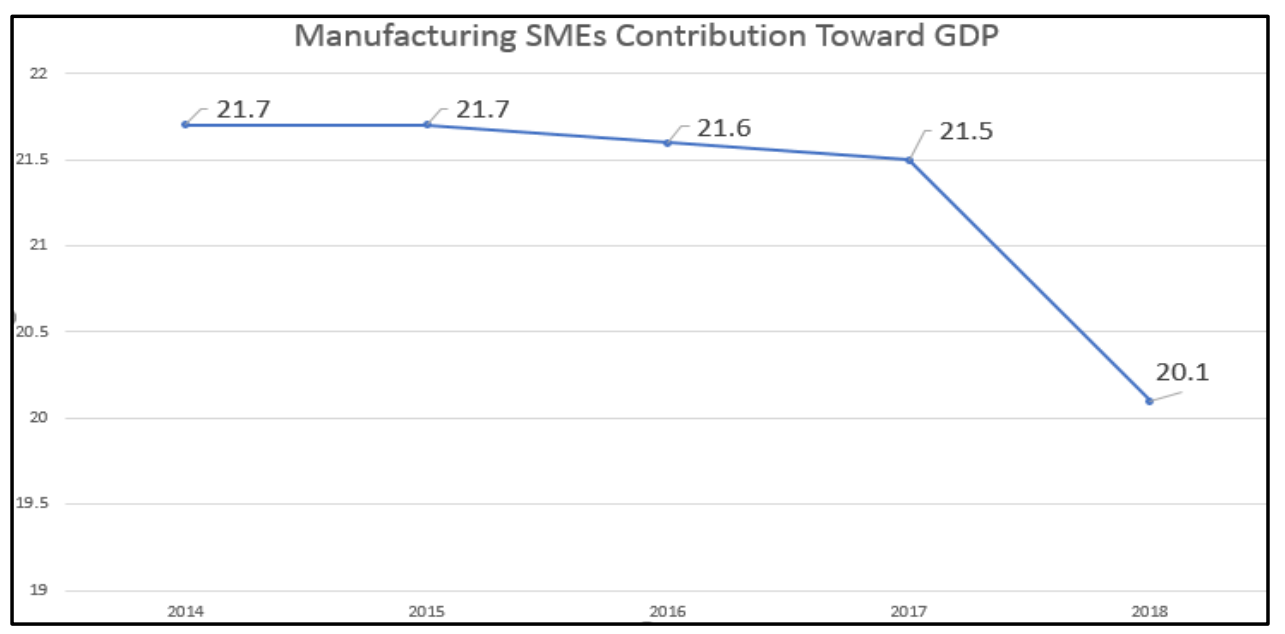

Source: (SME Corp, 2018)

Fig.1. Manufacturing SMEs Contribution to GDP between 2014-2018

Adopting intellectual capital could help develop marketing and management strategies, and it also plays a significant role in enhancing the firm's values and economic performance [12,13] Past study stated that intellectual capital is the source of wealth creation in any business [14]. It is not only that intellectual capital also helps increase the business performance and achieves a competitive edge. Moreover, investigations on intellectual capital and firm performance are lacking [15]. Thus, the present conceptual paper seeks to investigate the intellectual capital impact on firm performance of manufacturing SMEs in Malaysia. However, the present conceptual paper is of much significance in manufacturing SME's firm performance. Furthermore, the present paper's findings would be necessary for the practical, theoretical, and policy makers' perspectives. Manufacturing SMEs in Malaysia are facing issues regarding intellectual capital [16]. According to past literature, lack of intellectual capital practices such as skills, experience, insufficient knowledge, weak external relations, poor structures, lack of skilled and talented workers, which causes the quality of production to decline tremendously [16,17].

The main motive to conduct this conceptual framework is to fill the gap of [18] who suggested future research should examine the impact of intellectual capital on firm performance. Their findings cannot be generalized worldwide because it covers the data from only listed companies in ASX, and the findings are restricted only to 
Australian listed companies. Thus, this conceptual paper will provide valuable information and create awareness to the owner/managers of manufacturing SMEs in Malaysia about how organizational learning practices could improve their firm performance. Thus, the paper extends the current body of knowledge in both theoretical and practical areas.

\section{Literature Review}

\subsection{Firm Performance}

Firm performance measures performance indicators such as profits, growth, productivity, revenues, efficiency, and stock price [19]. Firm performance is divided into two (2) parts, financial and non-financial performance. The financial performance of the manufacturing SMEs can be measured based on revenue, profitability, reducing cost, return on assets and return on sales, according to [20]. However, the present conceptual paper proposed that firm performance would measure the financial performance of the manufacturing SMEs based on revenue, profitability, reducing cost, return on assets and return on sales.

\subsection{Intellectual Capital}

The intellectual capital term was first introduced by Galbraith as intangible resources in a firm with various resources such as knowledge, education, employee's competencies, skills, intellectual agility, customer relationships, brand names, and organizational structure. Table 1: introduce the various definition over the years by different authors regarding intellectual capital.

Table 1. Definitions of intellectual capital

\begin{tabular}{|c|c|}
\hline Author(s) & Definitions \\
\hline$[21]$ & $\begin{array}{r}\text { Intellectual capital is not only a static, intangible asset per se but an } \\
\text { ideological process, a means to an end. }\end{array}$ \\
\hline$[22]$ & $\begin{array}{r}\text { Brainpowers possessed by the members of the firm and their skills, } \\
\text { which has been turned into patents, trademarks, and brands. }\end{array}$ \\
\hline$[23]$ & $\begin{array}{r}\text { Knowledge, skills, know how, experiences of the company's } \\
\text { employees and its relationship with outside parties. }\end{array}$ \\
\hline$[24]$ & The accumulated value possessed by the employees. \\
\hline$[25]$ & The collective intangible assets and their stream of knowledge. \\
\hline$[26]$ & $\begin{array}{r}\text { The process of knowledge generation that might be leveraged into } \\
\text { some types of social and economic value. }\end{array}$ \\
\hline
\end{tabular}

Intellectual capital has been extensively studied within overall organizational performance SMEs [10,27], While acknowledging the contribution of SMEs towards the economy, studies have concluded that SMEs ' survival strongly depends upon their competitive and sustainable advantage [10]. In Malaysia, the researchers have stated 
that intellectual capital is not confined to understanding or illustrating unstated values of an organization; it is more about transposing the results of an organization's tacit values into new values [10]. The emphasis on having competitive advantages to the organization, which could depend both on physical and intellectual capital, has given the Malaysian authorities to place a considerable emphasis on intellectual capital [10]. According to [28,29], SMEs embed intellectual capital in ensuring their economic resilience and competencies in the era of globalization and rapid technological changes. Malaysia shows that SMEs have been interested in emphasizing intellectual capital. It considers the pursuit of effective use of knowledge embedded in human intellect, organizational routines, and market relationships [16]. The majority of Malaysian SMEs remain with little consideration on the intellectual capital, while this issue remains relatively under-researched about SMEs. Therefore, to increase the competitiveness and performance of Malaysian SMEs, the Malaysian government strongly supports the intellectual capital and what comes under it from skills, knowledge, relationships, and structure [13].

\subsection{Intellectual Capital and Firm Performance}

The significance of competitive advantages for a firm is critical, while competitive advantages depend on physical and intellectual capital. It is found to strongly influence organizational efficiency, productivity, and performance [13]. Intellectual capital is an essential intangible resource for a firm, where various researchers argued that intellectual capital plays a significant role in creating value for the firm [14]. In order to increase the business performance and achieving a competitive edge, intellectual capital was found to be the only source of wealth creation in a business, while the investigation of the relationship between intellectual capital and firm performance [30]. Past study measured the impact of intellectual capital on firm performance through productivity and profitability; the study has found that intellectual capital has a positive impact on organizational performance [31]. The intellectual capital of a firm represents the wealth of ideas and the ability to innovate, which will define the firm's future.

Meanwhile, from a theoretical and empirical point of view, it has been stated that intellectual capital affects the performance of an organization that adequately used its intangible resources and assets that contribute to the level of competitiveness and efficiency. Therefore, the financial performance of a company is not the primary determinant of the overall performance of a firm, but to its intangible assets in which knowledge and proficiency have become the most significant assets on a firm $[5,32,33]$. The impact of intellectual capital on firm performance has been studied since the early 2000 s.

A variety of measurement models has been used, and the findings were mixed. Based on those findings, it is far more complex to answer the research question concerning whether intellectual capital has any systematic influence on the firm performance? Intellectual capital is considered a resource that can be confirmed as intangible resources of a firm that are unambiguously connected to the organization's strategy [34]. Intellectual capital has been categorized as one of the most critical factors influencing overall firm performance [35]. There are various benefits of intellectual capital toward organizational performance; such benefits are considered indirect through applying innovation, human resource practices, and leadership style [20]. Various previous researchers have shown that intangible resources such as intellectual capital would help firms gain efficiency, strengthen core competencies and 
improve the overall performance of a firm [5]. Consequently, [36] proposed a broader perspective about intellectual capital that is emphasizing, which resulting in higher profitability and competitiveness in the long term $[32,33,36]$. Past studies have found that intellectual capital positively affects organizational performance [14,37]. Moreover, the majority of empirical literature suggests that intellectual capital and its components are associated with improved firm performance [38-42]. Previous findings stated that the relationship between firm performance and intangible resources remains with a limited understanding, indicating the need for further investigation [43]. Based on the discussed literature, the following hypothesize was proposed:

$\mathbf{H}_{1}$ : There is a positive relationship between intellectual capital and firm performance

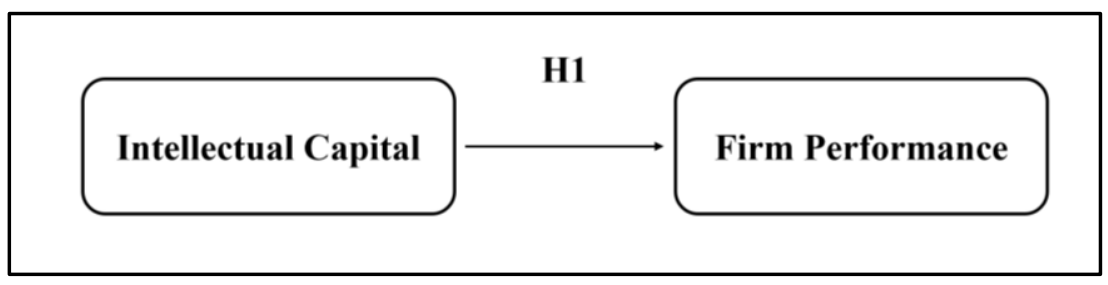

Fig.2. Conceptual Framework

Based on the literature review, many past studies mostly found that intellectual; capital positively influences firm performance. Thus, when intellectual capital activities increase, this will also improve the Manufacturing SME's firm performance. Moreover, the relationship between intellectual capital and firm performance is expected to be strong.

\subsection{Underpinning Theory}

\subsubsection{Resource-Based View theory}

Resource-based view theory (RBV) theory is used in studies to help provide an explanation for firm resources used and result in differences of performance measure by firms that engaged in intellectual capital [44,45]. However, the modern approach to analyzing the competitive advantage's sustainability is the (RBV) theory. This theory has begun in the middle of the 1980s by [46]. It has been developed and enhanced by two authors, [47,48], where they help give further understanding of the theory. (RBV) theory is comprehended by most firms. At the same time, [49] has given a brief notion of the (RBV) theory that could help in bringing out the equilibrium orientation of the (RBV) theory. According to [50], (RBV) theory is underscored by the fundamental concern of its resources endowment of financial capital, physical capital, intellectual capital. Moreover, their resources constitute (capabilities, processes, assets, and knowledge, brand names, the technology of skilled person, trade contact, machinery, efficient procedures, and capital, etc.) under the total control of the firm $[46,51,52]$

Previous studies in the context of intellectual capital have used various theories, such as knowledge-based theory. Neither knowledge-based view theory, which is mainly focused on the knowledge of employee's regardless of other human resources such as experience, skills, and abilities [53,54], or contingency theory which focused on the concept that constitutes varying variables [44] are suitable to study the impact of intellectual capital on firm performance. Hence, for firms to have sustainable competitive advantages, resources or combined resources remain secured to recent easy accessibility in the open market [55]. Furthermore, (RBV) theory is found the most 
suitable in underpinning the theoretical model of investigating the impact of resources allocation on intellectual capital development $[32,36,54]$.

\subsubsection{Intellectual Capital and Resource-Based View (RBV) Theory}

It is well acknowledged that a company's assets do not all have the same core value. Most strategists believe that intellectual capital is more critical than physical capital $[56,57]$. This is due to its ability to increase value without reducing itself when put into reality. As a result, the resource-based view theory emphasizes the relevance of both tangible and intangible resources for competitive advantage, laying the groundwork for a greater understanding of the value of intellectual capital for businesses [58]. According to past study, firms endowed with resources may derive competitive advantages when those resources are valuable, rare, inimitable, and non-substitutable [44].

Moreover, firm performance might be impacted by those resources only when they are well managed and utilized to achieve superior performance [44]. Firms can derive effectiveness and efficiency in their operation from resources considered valuable and are effectively utilized to help in implementing the competitive advantage. According to [59] strategic utilization of these resources will give firms longer competitive advantages. A resource will have competitive advantages when it is non-substitutable, rare, and inimitable [55].

\section{Research Design/Methodology/Approach}

A systematic review was conducted by five (5) reviewers who focus on the acquisition and synthesis of information blindly and in tandem. Furthermore, the review approach was well-developed in order to reduce biases and exclude obsolete or low-quality research. In systematic analysis, the first step is to adequately develop the study subject, followed by implementing a process. Furthermore, using a systematic review approach, it is essential to do a thorough and objective literature review. As a result, all results will be available to all findings, including those particularly important to our work. That is why a systematic review must be thorough, accurate, and repeatable; these traits separate a systematic review from traditional narrative research.

\section{Results and Discussion}

A detailed review of academic journals, proceedings, conferences, and books relevant to the keywords and study field was used to create the conceptual paper. Based on the extent of the literature review and the research disagreement, the following theoretical structure was established (Figure 2).

\section{Study Implication}

This paper acts as a platform for Manufacturing SMEs and the Malaysian government to place a more significant and revived emphasis on firm success facets and determinants. The current conceptual paper can conclude that intellectual capital is a significant antecedent of firm success based on the results of previous studies. The conceptual framework has not been tested empirically.

Other influencing variables, such as knowledge and process management, may have been included in future studies. Other independent variables, such as innovation performance, and moderating variables, such as innovation capability, may be considered in future research and experimentally tested. A comparative analysis of 
SMEs' intellectual capital on environmental issues, such as environmental performance, could be conducted in the future. Future research may also explore the impact of other independent, mediating, or moderating variables that could extend the present paper's theoretical model.

\section{Conclusion}

This conceptual paper focuses on intellectual capital importance and its impact on firm performance. High emphasis on intellectual capital investment in Malaysian SMEs would also motivate other firms to utilize the firm's resources efficiently. The present conceptual paper explained how intellectual capital could be used to generate superior performance. Firms should effectively exploit their firm's resources to enjoy superior performance. As a result of the fast-changing market trends and competitive market, SMEs must employ various methods to get a competitive advantage in providing better products or services to meet the demands of their clients. This paper will provide an impetus for Manufacturing SMEs owner/managers and the government of Malaysia to give greater and renewed focus to the aspects of firm performance and its influencers. Based on the past literature and findings, the present study can argue that intellectual capital is the essential antecedent of firm performance. Despite contributions and implications, the study is not free from limitations. It has some limitations that are acknowledged here. Firstly, the paper studied the impact of intellectual capital on firm performance from a conceptual perspective and has not been studied. Future researchers can conduct the present paper's framework. Secondly, the paper was limited to a single sector in Malaysian SMEs; future studies can study other sectors than manufacturing, such as the service or construction sector. Thirdly, future researchers can expand the framework by examining other factors, such as organizational learning and the mediating role of innovation capability.

\section{Declarations}

\section{Source of Funding}

This research did not receive any grant from funding agencies in the public, commercial, or not-for-profit sectors.

\section{Competing Interests Statement}

The authors declare no competing financial, professional and personal interests.

\section{Consent for publication}

Authors declare that they consented for the publication of this research work.

\section{References}

[1] Asiaei, K., Jusoh, R., Bontis, N. Intellectual capital and performance measurement systems in Iran. J. Intellect. Cap. 2018, 19, 294-320, doi: 10.1108/JIC-11-2016-0125.

[2] Asiaei, K., Jusoh, R. Using a robust performance measurement system to illuminate intellectual capital. Int. J. Account. Inf. Syst. 2017, 26, 1-19, doi: 10.1016/j.accinf.2017.06.003.

[3] Hudson, B. Penal policy and social justice, Macmillan International Higher Education, 1993, ISBN 1349230715. 
Asian Journal of Basic Science \& Research

Volume 3, Issue 4, Pages 72-82, October-December 2021

[4] Ahmed, S.S., Guozhu, J., Mubarik, S., Khan, M., Khan, E. Intellectual capital and business performance: the role of dimensions of absorptive capacity. J. Intellect. Cap. 2019, 21, 23-39, doi: 10.1108/JIC-11-2018-0199.

[5] Cisneros, M.A.I., Hernandez-Perlines, F. Intellectual capital and Organization performance in the manufacturing sector of Mexico. Manag. Decis. 2018.

[6] Daou, A., Karuranga, E., Su, Z. Towards a better understanding of intellectual capital in Mexican SMEs. J. Intellect. Cap. 2014, 15, 316-332, doi: 10.1108/JIC-08-2013-0092.

[7] Saleh, A.S., Ndubisi, N.O. An evaluation of SME development in Malaysia. Int. Rev. Bus. Res. Pap. 2006, 2, $1-14$.

[8] Ismail, M. Corporate social responsibility and its role in community development: An international perspective. J. Int. Soc. Res. 2009, 2.

[9] Hilmi, M.F., Thurasamy, R., Mustapha, Y., Pawanchik, S. Exploring intellectual capital of Malaysian small and medium entrepreneurs. In Proceedings of the 2011 IEEE Colloquium on Humanities, Science and Engineering, IEEE, 2011, pp. 626-631.

[10] Khalique, M., Bontis, N., Bin Shaari, J.A.N., Isa, A.H.M. Intellectual capital in small and medium enterprises in Pakistan. J. Intellect. Cap. 2015.

[11] Montes, N.B.D., Baticados, G.N. Small and Medium Enterprises in the Malaysian Economy: Some Lessons Learned for SME Development in the Philippines. J. Econ. Manag. Agric. Dev. 2016, 2, 55-74.

[12] Palazzi, F., Sgrò, F., Ciambotti, M., Bontis, N. Technological intensity as a moderating variable for the intellectual capital-performance relationship. Knowl. Process Manag. 2020, 27, 3-14, doi: 10.1002/kpm.1617.

[13] Bin Shaari, J.A.N., bin Md Isa, A.H., Khalique, M. Impact of intellectual capital on organizational performance of ICT SMEs in Penang, Malaysia. Mark. Forces 2018, 13.

[14] Musteen, M., Ahsan, M., Park, T. SMEs, Intellectual Capital, and Offshoring of Service Activities: An Empirical Investigation. Manag. Int. Rev. 2017, 57, 603-630.

[15] Muda, I., Roosmawati, F., Siregar, H.S., Manurung, H., Banuas, T. Performance Measurement Analysis of Palm Cooperative Cooperation with Using Balanced Scorecard. In Proceedings of the IOP Conference Series: Materials Science and Engineering, IOP Publishing, 2018, Vol. 288, p. 12081.

[16] Muda, S., Che Abdul Rahman, M.R. Sectoral effects of intellectual capital on Malaysian SME business performance. Asia-Pacific Manag. Account. J. 2019, 14, 153-175.

[17] Khalique, M., Hina, K., Ramayah, T., bin Shaari, J.A.N. Intellectual capital in tourism SMEs in Azad Jammu and Kashmir, Pakistan. J. Intellect. Cap. 2020.

[18] Amin, S., Usman, M., Sohail, N., Aslam, S. Relationship between intellectual capital and financial performance: The moderating role of knowledge assets. Pakistan J. Commer. Soc. Sci. 2018, 12, 521-547.

[19] Gërguri-Rashiti, S., Ramadani, V., Abazi-Alili, H., Dana, L., Ratten, V. ICT, innovation and firm performance: the transition economies context. Thunderbird Int. Bus. Rev. 2017, 59, 93-102. 
Asian Journal of Basic Science \& Research Volume 3, Issue 4, Pages 72-82, October-December 2021

[20] Khalique, M., Bontis, N., Bin Shaari, J.A.N., Yaacob, M.R., Ngah, R. Intellectual capital and organisational performance in Malaysian knowledge-intensive SMEs. Int. J. Learn. Intellect. Cap. 2018, 15, 20-36, doi: 10.1504/ IJLIC.2018.088345.

[21] Bontis, N. Intellectual capital: an exploratory study that develops measures and models. Manag. Decis. 1998, 36, 63-76, doi: 10.1108/00251749810204142.

[22] Roos, J., Roos, G., Dragonetti, N.C., Edvinsson, L. Developing an Intellectual Capital System: the Process Model. In Intellectual Capital, Springer, 1997, pp. 59-77.

[23] Edvinsson, L., Malone, M. Realizing your company's true value by finding its hidden brain power. Intellect. Cap. 1997.

[24] Stewart, T.A. Intellectual capital: the new wealth of organizations, Bantam Doubleday Dell Publishing Group. Inc., New York, NY 1997.

[25] Bontis, N., Girardi, J. Teaching knowledge management and intellectual capital lessons: an empirical examination of the TANGO simulation. Int. J. Technol. Manag. 2000, 20, 545-555.

[26] Jørgensen, K.M. Conceptualising intellectual capital as language game and power. J. Intellect. Cap. 2006.

[27] Khalique, M., Shaari, J.A.N.B., Isa, A.H.B.M. The road to the development of intellectual capital theory. Int. J. Learn. Intellect. Cap. 2013, 10, 122-136, doi: 10.1504/IJLIC.2013.052953.

[28] Kamaluddin, A., Arshad, R., Akmal Hasan, H., Abu Samah, S.A. Social capital and innovation capital: accountability towards small medium enterprises' (SMEs) sustainable performance. Manag. Account. Rev. 2016, $15,1-28$.

[29] Khalique, M., Pablos, P.O. de Intellectual capital and performance of electrical and electronics SMEs in Malaysia. Int. J. Learn. Intellect. Cap. 2015, 12, 251-269.

[30] Cleary, P., Quinn, M. Intellectual capital and business performance: An exploratory study of the impact of cloud-based accounting and finance infrastructure. J. Intellect. Cap. 2016, 17, 255-278, doi: 10.1108/JIC-062015-0058.

[31] Iqbal, A., Latif, F., Marimon, F., Sahibzada, U.F., Hussain, S. From knowledge management to organizational performance: Modelling the mediating role of innovation and intellectual capital in higher education. J. Enterp. Inf. Manag. 2019.

[32 Kengatharan, N. A knowledge-based theory of the firm: Nexus of intellectual capital, productivity and firms' performance. Int. J. Manpow. 2019, doi: 10.1108/IJM-03-2018-0096.

[33] McDowell, W.C., Peake, W.O., Coder, L.A., Harris, M.L. Building small firm performance through intellectual capital development: Exploring innovation as the "black box." J. Bus. Res. 2018, 88, 321-327, doi: 10. 1016/j.jbusres.2018.01.025.

[34] Manes Rossi, F., Citro, F., Bisogno, M. Intellectual capital in action: evidence from Italian local governments. J. Intellect. Cap. 2016, 17, 696-713, doi: 10.1108/JIC-01-2016-0011. 
[35] Anwar, M., Khan, S.Z., Khan, N.U. Intellectual capital, entrepreneurial strategy and new ventures performance: Mediating role of competitive advantage. Bus. Econ. Rev. 2018, 10, 63-93.

[36] Ahmed El-Imam, A.M., Greetham, D., Du, C., Dyer, P.S. The development of a biorefining strategy for the production of biofuel from sorghum milling waste. Biochem. Eng. J. 2019, 150, doi: 10.1016/j.bej.2019.107288.

[37] Scafarto, V., Ricci, F., Scafarto, F. Intellectual capital and firm performance in the global agribusiness industry. J. Intellect. Cap. 2016, 17, 530-552, doi: 10.1108/jic-11-2015-0096.

[38] Jardon, C.M., Martos, M.S. Intellectual capital as competitive advantage in emerging clusters in Latin America. J. Intellect. Cap. 2012.

[39] Kamukama, N., et al. Intellectual capital and performance: testing interaction effects. J. Intellect. Cap. 2010.

[40] Kim, E.A., Jang, K.S. Development of a measurement of intellectual capital for hospital nursing. J. Korean Acad. Nurs. 2011, 41, 129-140, doi: 10.4040/jkan.2011.41.1.129.

[41] Maditinos, D., Sevic, Z., Tsairidis, C. Intellectual capital and business performance: an empirical study for the Greek listed companies. 2010.

[42] Sharabati, A.A., Jawad, S.N., Bontis, N. Intellectual capital and business performance in the pharmaceutical sector of Jordan. Manag. Decis. 2010.

[43] Gogan, L.M., Artene, A., Sarca, I., Draghici, A. The impact of intellectual capital on organizational performance. Procedia-social Behav. Sci. 2016, 221, 194-202.

[44] Othman, S., et al. The conceptual framework on social entrepreneurship activities as a mediator between social capital and the performance of Malaysian small and medium enterprises (SMEs). J. Educ. Soc. Sci. 2017, 110-114. [45] Panda, D., Reddy, S. Resource based view of internationalization: evidence from Indian commercial banks. J. Asia Bus. Stud. 2016.

[46] Wernerfelt, B. A resource-based view of the firm. Strateg. Manag. J. 1984, 5, 171-180.

[47] Rumelt, R.P. Towards a strategic theory of the firm. Compet. Strateg. Manag. 1984, 26, 556-570.

[48] Barney, J.B. Types of competition and the theory of strategy: Toward an integrative framework. Acad. Manag. Rev. 1986, 11, 791-800.

[49] Peteraf, M.A. The cornerstones of competitive advantage: a resource-based view. Str. M. J. 1993, 179-191.

[50] Chan, H.K., Yee, R.W.Y., Dai, J., Lim, M.K. The moderating effect of environmental dynamism on green product innovation and performance. Int. J. Prod. Econ. 2016, 181, 384-391.

[51] Ford, Paladino, Enabling innovation through strategic synergies. J. Prod. Innov. Manag. 2013, 30, 1058-1072. [52] Penrose, E.T. The Theory of the Growth of the Firm. New York: John Wiley \& Sons Inc. Penrose, E. T 1959, $1,1-23$.

[53] Barkat, W., Beh, L.S. Impact of intellectual capital on organizational performance: Evidence from a developing country. Acad. Strateg. Manag. J. 2018, 17, 6104. 
[54] Waseem, B., Loo-See, B., Adeel, A., Riaz, A. Impact of intellectual capital on innovation capability and organizational performance: An empirical investigation. Serbian J. Manag. 2018, 13, 365-379.

[55] Hitt, M.A., Xu, K., Carnes, C.M. Resource based theory in operations management research. J. Oper. Manag. 2016, 41, 77-94.

[56] Ahonen, G. Generative and commercially exploitable intangible assets. Classif. Intangibles 2000, 206-213.

[57] Roos, G., Pike, S., Fernstrom, L. Managing Intellectual Capital In Practice. Butterworth Heinemann 2005.

[58] Curado, C., Bontis, N. The knowledge-based view of the firm and its theoretical precursor. Int. J. Learn. Intellect. Cap. 2006, 3, 367-381.

[59] Singh, H., Mahmood, R. Combined effect of competitive and manufacturing strategies on export performance of small and medium enterprises in Malaysia. Glob. J. Manag. Bus. Res. 2014. 